\title{
Herland by Charlotte Perkins Gilman First Edition, Pantheon Books, New York, 1979, 147 pages
}

\author{
Arzu ÖZYÖN*
}

Charlotte Perkins Gilman's feminist novel Herland written in 1892, and giving an utopic vision of an all-female society is still among the most outstanding feminist woman writing in America. It assured its place among the first feminist utopian works in such a strong and safe way that it has never been shaken so far.

The permanence and the success of Herland is mostly due to its being a multi-dimensional work. With its all-female culture, it creates an utopian-never existing- world, and also creates an alternative society to the already existing patriarchal one; as a feminist work it criticizes the patriarchal society drawing some certain lines/roles for women depending on the outdated Victorian idea(l) $\mathrm{s}$ and view of woman. It also presents a wide range of opportunities for cultural studies such as cultural feminism, and cultural ecology.

The novel gives an account of the adventures of three men, three intruders called Vandyck, Terry and Jeff trespassing the undiscovered land of an all-female society called Herland and their relationship with the Herlanders, Ellador, Alima and Celis and three old tutors there. The novel divided into twelve chapters depicts what these three men with totally different character traits from each other, experienced in Herland.

What distinguishes Gilman's novel, Herland from the works of her contemporaries is that she dares to create a society composed only of females as

\footnotetext{
* Kütahya Dumlupınar Üniversitesi, Yabancı Diller Yüksekokulu, Yabancı Diller Bölümü. Türkiye. Elmek: arzu.ozyon@dpu.edu.tr https://orcid.org/0000-0003-2730-9676
} 
an alternative to the already-present patriarchal society and in spite of their strict rules at that time: "There was literally no one left on this beautiful high garden land but a bunch of hysterical girls and some older slave women." (Herland, 55) And with her radical feminist approach she depicts all these women as strong as men, totally contrary to what was generally accepted in the Victorian period. These women are Mothers still, as they themselves emphasize, however not the type of mothers as depicted in that period. As Vandyck stresses in the novel, "You see, they were Mothers, not in our sense of helpless involuntary fecundity, forced to fill and overfill the land, every land, and then see their children suffer, sin and die, fighting horribly with one another; but in the sense of Conscious Makers of People" (Herland, 68). They are neither fragile nor need any men to continue their lives. They seem to have the strength to be both mothers and fathers for their children. They are completely the opposite of "the angel in the house" since they are not only physically but also psychologically strong and as free as birds in their peaceful and flourishing land in every respect. Freedom is such a natural phenomenon for the Herlanders that they cannot understand why the women in the other world are kept inside houses: "And two-thirds are the ones who are-how was it you so beautifully put it?- 'loved, honored, kept in the home to care for the children" (Herland, 63). And they raise their children (the only centre of their focus) to be like themselves both physically and psychologically strong and free:

Let me see- with us, children- minors, that is- constitute about three-fifths of the population; with them only about one-third, or less. And precious--! No sole heir to an empire's throne, no solitary millionaire baby, no only child of middle-aged parents, could compare as an idol with these Herland children (Herland, 71).

As Vandyck points out these children are not only healthier physically and mentally, and raised more freely but also, they are a happier and more satisfied generation compared to the children of the Americans. And their mothers, the Herlanders, let alone being an angel or being fragile like the Victorian type of women, do not seem to have any feelings, not even the most basic feelings like love or hatred. Therefore, what Gilman imagines and creates is a world that is ahead of the times she lived in.

Hence, Gilman in Herland, turns all the patriarchal values, their beliefs and also prejudices about women upside down. She does this by using the three men 
who intrudes in the lives of her female characters and actually by ridiculing these three men in many parts of her novel: "Instantly each of us was seized by five women, each holding arm or leg or head; we were lifted like children, straddling helpless children, and borne onward, wriggling indeed, but most ineffectually" (Herland, 23). Not only does she ridicule them but also, she questions and at most times makes them question their seemingly unquestionable and unshakeable patriarchal values and beliefs.

Another outstanding point about the novel seems to be the opportunities it presents for various studies in the fields of cultural feminism, cultural ecology and even Amazon feminism. Since the women live a somewhat primitive life in the heart of nature, the novel may allow the researchers and academics to focus on the subject of ecology. And others may find the feminist side of Herland more interesting which might enable them to study either on the cultural or Amazon feminism as a more extreme one.

To sum up, Herland is a novel that will be read in a breath with its gripping story. Although it is divided into chapters it does not give any harm to the flow and the fluency of the story. On the contrary, it enables the reader to read the novel easily and to give a break whenever s/he wishes or needs. What makes it even more gripping is the fact that it has an open-ending:

\footnotetext{
'So we have this to ask of you gentlemen [they knew that word was held a title of honor with us], that you promise not in any way to betray the location of this country until permission- after Ellador's return.' [...] With which agreement we at last left Herland (Herland, 145-146).

Thus, it leaves the conclusion of the story to the reader, who otherwise is triggered to read the second book of the trilogy to learn what happens to the two protagonists of Herland Ellador and Vandyck who travel to Ourland (in With Her in Ourland) to experience more adventures.
} 